\title{
A Experiência Eleitoral em Campos dos Goytacazes (1870-1889): Freqüência Eleitoral e Perfil da População Votante*
}

\author{
Neila Ferraz Moreira Nunes
}

\section{APRESENTAÇÃO}

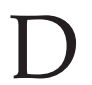
otado de um dos mais expressivos eleitorados do mundo ${ }^{1}$, o Brasil possui uma rica história eleitoral, cuja trajetória foi marcada por avanços e retrocessos no que se refere à representatividade social da população legalmente habilitada ao voto. As primeiras eleições gerais do país ocorreram quando da escolha dos representantes brasileiros às Cortes de Lisboa (1821). Posteriormente, a Constituição de 1824 e uma série de leis subseqüentes deram forma ao sistema eleitoral que vigorou no Império, cuja arquitetura previa eleições em dois níveis: votavam em primeira instância (eleições primárias) aqueles que escolhiam os eleitores responsáveis pelas eleições secundárias ${ }^{2}$. Pela legislação, ficavam excluídos do processo eleitoral as mulheres, os escravos, os menores de 25 anos (com algumas exceções), os praças de pré do Exército, da Armada e da força policial paga, assim como os marinheiros dos navios de guerra. A adoção do voto censitário exigia, ainda, um patamar mínimo de renda anual para que um cidadão pu-

\footnotetext{
* Artigo extraído da Dissertação de Mestrado Eleições e Poder no Império: A Experiência Eleitoral em Campos dos Goytacazes (1870-1889), defendida no IUPERJ em maio de 2002.
}

DADOS - Revista de Ciências Sociais, Rio de Janeiro, Vol. 46, no2, 2003, pp. 311 a 343. 
desse qualificar-se como votante: 100 mil réis a princípio e 200 mil réis a partir de $1846^{3}$.

De maneira geral, no século XIX, os padrões eleitorais internacionalmente praticados eram elitistas e excluíam parte significativa da população que estava na base da pirâmide socioeconômica. Nesse ambiente, o Brasil não é uma exceção à regra. Entretanto, um olhar anacrônico sobre a realidade do voto no Império brasileiro pode sugerir uma visão distorcida sobre a representatividade social da prática eleitoral do período. Isto porque, avaliados a partir de critérios atuais, os limites então adotados parecem por demais rigorosos, quando, na verdade, estavam de acordo com o seu tempo e com o pensamento político da época.

A eleição censitária foi talvez o elemento que mais contribuiu para interpretações precipitadas sobre a representatividade do voto no país. Por muito tempo, as análises sobre a realidade eleitoral no Império brasileiro (ver Alencar, 1997; Souza, 1979; Holanda, 1972; Faoro, 1998; Leal, 1986) priorizaram questões, tais como as imperfeições da legislação, o caráter fraudulento da prática eleitoral (associado ao clientelismo e ao uso autoritário do poder) e a circunstância de as eleições não representarem um canal de fato para mudanças no status quo do poder político, estando a serviço da produção continuada de "câmaras unânimes e governistas" e da alternância artificial dos partidos no poder. Tais análises deram lugar a interpretações pouco precisas sobre a representatividade do voto no Império. Assim, por exemplo, muitos dos livros-textos de história, ainda hoje adotados no ensino médio, reafirmam a visão de que o processo eleitoral do período, por ser censitário, implicava eleições pouco freqüentes e carentes de ampla participação popular ${ }^{4}$. No entanto, já há algum tempo, trabalhos sobre o tema têm procurado relativizar os efeitos da exigência da renda mínima sobre a limitação do voto, buscando dimensionar o real significado dos 200 mil réis para o padrão de riqueza da época (Buesco, 1981:183; Linhares, 1979:141). Ademais, novas pesquisas vêm produzindo uma literatura que sublinha o fato de que o percentual de votantes no Brasil imperial se traduzia em um índice de inclusão política que não ficava nada a dever aos então observados nos países da Europa Ocidental ${ }^{5}$.

O alto grau de inclusão eleitoral observado no Brasil imperial é compreensível se considerarmos que as instituições do regime monárqui- 
co que se seguiu à emancipação política do país (1822) foram modeladas tendo como referência as experiências políticas mais avançadas da Europa Ocidental. De fato, essa circunstância implicou a adoção do sistema representativo e de uma monarquia dotada de elementos constitucionais, tais como divisão de poderes, partidos políticos e eleições.

Vale lembrar ainda que análises baseadas em Listas de Qualificação de Votantes têm revelado surpreendentes resultados no que diz respeito aos índices de participação eleitoral em diversas regiões do país, como Curitiba (Cardoso, 1974), Campinas (Magalhães, 1992), São Paulo (Klein, 1995) e Município da Corte (Linhares, 1979), e permitido, simultaneamente, desenhar um perfil mais realista do eleitorado brasileiro no terceiro quarto do século XIX.

O presente trabalho tem por objetivo retomar a questão da participação eleitoral e do perfil dos votantes (idade, instrução, renda e ocupação profissional), tendo como referência as listas de qualificação de votantes $^{6}$ de Campos dos Goytacazes (RJ). Com base no caso deste município, discute ainda a freqüência de eleições no período focalizado (1870-1889). Embora induzido pela disponibilidade de dados primários (as listas de qualificação franqueadas), o corte temporal utilizado atravessa três momentos particulares da vida eleitoral brasileira. No primeiro deles (1870-1875), está em vigor a Segunda Lei do Círculo; o segundo (1875-1881) corresponde a uma conjuntura na qual a Lei do Terço organiza o processo eleitoral brasileiro; o terceiro (1881-1889) equivale a um período sob regulação da Lei Saraiva.

É importante registrar que o Município de Campos ocupou durante todo o Império uma posição relevante no cenário eleitoral da província, mantendo sempre a condição de "cabeça de distrito". Em 1866, os maiores colégios eleitorais da Província do Rio de Janeiro eram: Campos (100 eleitores), Niterói (88), Piraí (73), Itaguaí (68), Barra Mansa e Angra dos Reis (65 cada). Em 1881, Niterói, com 1.131 eleitores, e Campos, com 1.108, permaneciam como os principais colégios eleitorais provinciais, seguidos por Valença (602), São Fidélis (588) e Rezende $(514)^{7}$.

\section{QUANTO SE VOTA NO IMPÉRIO: A FREQÜÊNCIA DE EVENTOS ELEITORAIS EM CAMPOS DOS GOYTACAZES}

Um inventário dos pleitos eleitorais ocorridos em Campos dos Goytacazes no período 1870-1889 revela que se votava muito no 
Império. À exceção de três anos, 1871,1879 e 1888, há no município registro de pelo menos um evento eleitoral por ano (ver Quadros 1 e 2). O quadro encontrado para a região pode, muito provavelmente, ser estendido para a província e para o país.

\section{Quadro 1}

Município de Campos dos Goytacazes

Freqüência de Eventos Eleitorais no Império (1870-1880)

\begin{tabular}{|c|c|c|c|c|c|c|}
\hline \multirow[b]{2}{*}{ Ano } & \multicolumn{6}{|c|}{ Tipo de Eleição para } \\
\hline & Eleitores & $\begin{array}{l}\text { Juízes } \\
\text { de Paz }\end{array}$ & $\begin{array}{c}\text { Câmara } \\
\text { Municipal }\end{array}$ & $\begin{array}{c}\text { Ass. } \\
\text { Provincial }\end{array}$ & Ass. Geral & Senado \\
\hline 1870 & & & & $\begin{array}{c}20 / 2- \\
\text { eleição geral }\end{array}$ & & \\
\hline \multicolumn{7}{|l|}{1871} \\
\hline 1872 & $\begin{array}{c}18 / 8- \\
\text { eleição geral } \\
10 / 11 \text { - } \\
\text { eleição } \\
\text { especial }\end{array}$ & $\begin{array}{c}7 / 9- \\
\text { eleição geral }\end{array}$ & $\begin{array}{c}7 / 9- \\
\text { eleição geral }\end{array}$ & $\begin{array}{c}11 / 3- \\
\text { eleição geral }\end{array}$ & $\begin{array}{c}18 / 9- \\
\text { eleição geral }\end{array}$ & $\begin{array}{c}10 / 3- \\
1 \text { vaga } \\
19 / 11- \\
1 \text { vaga }\end{array}$ \\
\hline 1873 & & $\begin{array}{l}\text { 9/3 - Freg. } \\
\text { São Salv./ } \\
\text { Guarulhos }\end{array}$ & & & & \\
\hline 1874 & & & & $\begin{array}{c}25 / 1- \\
\text { eleição geral }\end{array}$ & & \\
\hline 1875 & & & & & $\begin{array}{l}12 / 8- \\
1 \text { vaga }\end{array}$ & \\
\hline 1876 & $\begin{array}{c}1^{\circ} / 10- \\
\text { eleição geral }\end{array}$ & $\begin{array}{c}1^{\circ} / 10- \\
\text { eleição geral }\end{array}$ & $\begin{array}{c}1^{\circ} / 10- \\
\text { eleição geral }\end{array}$ & $\begin{array}{c}20 / 2- \\
\text { eleição geral }\end{array}$ & $\begin{array}{c}31 / 10- \\
\text { eleição geral }\end{array}$ & \\
\hline 1877 & & $\begin{array}{c}\text { eleições } \\
\text { especiais } \\
\text { Dores e B. } \\
\text { Jesus }\end{array}$ & $\begin{array}{c}\text { eleições } \\
\text { especiais } \\
\text { Dores e B. } \\
\text { Jesus }\end{array}$ & & & \\
\hline 1878 & $\begin{array}{c}5 / 8- \\
\text { eleição geral }\end{array}$ & & & $\begin{array}{c}17 / 2- \\
\text { eleição geral } \\
6 / 10- \\
1 \text { vaga }\end{array}$ & $\begin{array}{c}4 / 9- \\
\text { eleição geral }\end{array}$ & \\
\hline 1879 & & & & & & \\
\hline 1880 & & $\begin{array}{c}1^{\circ} / 7- \\
\text { eleição geral }\end{array}$ & $\begin{array}{c}1^{\circ} / 7- \\
\text { eleição geral }\end{array}$ & $\begin{array}{c}1^{\circ} / 2- \\
\text { eleição geral }\end{array}$ & $\begin{array}{c}6 / 5- \\
1 \text { vaga }\end{array}$ & \\
\hline
\end{tabular}

Fontes: Elaboração própria, a partir de Relatórios dos Presidentes da Província do Rio de Janeiro e Monitor Campista. 
Quadro 2

Município de Campos dos Goytacazes

Freqüência de Eventos Eleitorais no Império (após a Lei Saraiva)

(1881-1889)

\begin{tabular}{|c|c|c|c|c|c|}
\hline \multirow[b]{2}{*}{ Ano } & \multicolumn{5}{|c|}{ Tipo de Eleição para } \\
\hline & Juízes de Paz & $\begin{array}{l}\text { Câmara } \\
\text { Municipal }\end{array}$ & Ass. Provincial & Ass. Geral & Senado \\
\hline 1881 & & & $\begin{array}{c}15 / 11-\text { eleição } \\
\text { geral ( } 1^{\circ} \text { esc.) } \\
20 / 12 \text { - eleição } \\
\left.\text { geral ( } 2^{\circ} \text { esc. }\right)\end{array}$ & $\begin{array}{c}31 / 10 \text { - eleição } \\
\text { geral ( } 1^{\circ} \text { esc.) } \\
7 / 12 \text { - eleição } \\
\text { geral ( } 2^{\circ} \text { esc.) }\end{array}$ & \\
\hline 1882 & $\begin{array}{c}2 / 7- \\
\text { eleição geral }\end{array}$ & $\begin{array}{c}2 / 7- \\
\text { eleição geral }\end{array}$ & & & \\
\hline 1883 & & & $\begin{array}{c}16 / 12- \\
\text { eleição geral } \\
\left(1^{\circ} \text { esc. }\right)\end{array}$ & & \\
\hline 1884 & & & $\begin{array}{c}23 / 1- \\
\text { eleição geral } \\
\left(2^{\circ} \text { esc. }\right)\end{array}$ & $\begin{array}{c}1^{\circ} / 12- \\
\text { eleição geral }\end{array}$ & $\begin{array}{l}17 / 8- \\
1 \text { vaga }\end{array}$ \\
\hline 1885 & & & $\begin{array}{c}31 / 11 \text { - eleição } \\
\left.\text { geral ( } 1^{\circ} \text { esc. }\right) \\
3 / 12-\text { eleição } \\
\left.\text { geral ( } 2^{\circ} \text { esc. }\right)\end{array}$ & & \\
\hline 1886 & $\begin{array}{c}1^{\circ} / 7- \\
\text { eleição geral }\end{array}$ & $\begin{array}{c}30 / 5- \\
1 \text { vaga } \\
1^{\circ} / 7 \text { - eleição } \\
\text { geral ( } 1^{\circ} \text { esc.) } \\
8 / 8 \text { - eleição } \\
\text { geral ( } 2^{\circ} \text { esc.) }\end{array}$ & & $\begin{array}{c}15 / 1- \\
\text { eleição geral }\end{array}$ & $\begin{array}{l}7 / 10- \\
1 \text { vaga }\end{array}$ \\
\hline 1887 & & & $\begin{array}{c}28 / 12- \\
\text { eleição geral }\end{array}$ & $\begin{array}{c}15 / 11- \\
1 \text { vaga }\end{array}$ & $\begin{array}{c}17 / 7- \\
1 \text { vaga } \\
10 / 11- \\
1 \text { vaga }\end{array}$ \\
\hline 1888 & & & & & \\
\hline 1889 & $\begin{array}{c}\text { Freg. S. José } \\
\text { do Avay }\end{array}$ & $\begin{array}{c}\text { 10/5 - Vila } \\
\text { Itaperuna } \\
8 / 9 \text { - 1 vaga }\end{array}$ & $\begin{array}{c}\text { ?/7 - } \\
\text { eleição geral }\end{array}$ & $\begin{array}{l}31 / 8- \\
1 \text { vaga }\end{array}$ & $\begin{array}{c}3 / 8- \\
1 \text { vaga }\end{array}$ \\
\hline
\end{tabular}

Fontes: Elaboração própria, a partir de Relatórios dos Presidentes da Província do Rio de Janeiro e Monitor Campista. 
O grande número de eleições explica-se por numerosos fatores. Havia casos em que em um mesmo município ou distrito eleitoral se realizavam duas eleições por ano. Como o Senado era uma Câmara vitalícia, as votações só aconteciam quando um de seus membros morria. Surgida a vaga, logo eram convocados os eleitores para a escolha do novo senador, e, por conseguinte, a ocorrência de mais de um pleito por ano não era incomum. Isto aconteceu em 1872, quando faleceram o visconde de Itaboray e o senador Cândido Borges Monteiro, e também em 1887, com os óbitos do conde de Baependy e do senador Antônio Chichorro. A Câmara Municipal ${ }^{8}$, Assembléia Geral e Assembléia Provincial poderiam passar por situação semelhante, porque, não havendo a figura do suplente, sempre que desocupava um cargo de vereador, deputado provincial ou deputado geral, o que acontecia por motivos diversos (transferências de cargo, morte etc.), uma eleição especial era convocada para o preenchimento da vaga correspondente.

As eleições para a Assembléia Geral, Câmara Municipal e para Juízes de Paz ocorriam de quatro em quatro anos, tempo de duração dos mandatos, enquanto para as Assembléias Provinciais, seguindo a legislação, realizavam-se a cada dois anos. Além disso, pleitos extraordinários para a Assembléia Geral eram freqüentes, em função de atos de dissolução da Câmara previstos pela legislação e operacionalizados pelos mecanismos inerentes ao sistema parlamentar em vigor.

Com a Reforma de 1881, a adoção do coeficiente eleitoral ${ }^{9}$ nas eleições de vereadores e deputados provinciais e do sistema de maioria absoluta nas eleições para a Assembléia Geral criou o segundo escrutínio, provocando, muitas vezes, uma duplicação de eleições. Os candidatos que não atingissem o coeficiente previsto ou a maioria absoluta dos votos, mesmo que fossem os mais votados, teriam que disputar as vagas em uma segunda eleição. Se levarmos em consideração o processo de qualificação de votantes ${ }^{10}$, podemos concluir que os eventos eleitorais foram uma constante na vida do cidadão brasileiro durante o Império, o que transparece com clareza na afirmação de um articulista da época: "Não há no mundo país, onde se fale tanto de política como no Brasil. Política, não digo bem, mas por eleições nenhum povo tem mais paixão do que o brasileiro"11. 


\section{CAMPOS DOS GOYTACAZES: AS LISTAS DE QUALIFICAÇÃO}

A chamada Lei do Terço (1875), responsável pela criação dos títulos de qualificação de votantes, introduziu uma importante inovação ao exigir a ampliação das informações contidas nas listas preparadas durante o processo de alistamento. A partir de então, as listas de qualificação de votantes (organizadas por distritos e quarteirões) passaram a registrar os nomes dos qualificados inscritos por ordem alfabética e uma série de informações adicionais, visto que, conforme previa a legislação, "em frente do nome de cada um destes se mencionarão a idade, a profissão, a circunstância de saber ler ou não ler e escrever, a filiação, o domicílio e a renda conhecida provada ou presumida" (art. 27) ${ }^{12}$. Assim, o processo de qualificação acabou produzindo um importante documento, com dados suficientes para permitir estudos mais sólidos acerca do perfil socioprofissional do eleitorado das diversas paróquias e municípios do país.

A análise apresentada na próxima seção deste trabalho tem como base três listas de qualificação, referentes ao Município de Campos, encontradas em trabalho de pesquisa em arquivos públicos do município. Uma delas refere-se à paróquia de São Salvador (1876), outra à paróquia de São Gonçalo (1878) e a terceira à freguesia de Nossa Senhora da Natividade do Carangola (1878). A paróquia de São Salvador era, já nesse período, uma freguesia urbana e a mais importante do município. A de São Gonçalo, próxima à sede do município (hoje integra a região metropolitana da cidade), embora rural, possuía um grau de urbanização mais elevado que a de Natividade, esta sim uma paróquia tipicamente rural. O reduzido número de documentos encontrados não permitiu a organização de uma série temporal que possibilitasse identificar tendências e transformações do perfil dos votantes ao longo do tempo; fornecem, entretanto, um retrato bem definido da população qualificada das paróquias de referência e representam uma amostra bastante significativa do eleitorado total do município (ver Tabelas 1 e 2). As três paróquias analisadas englobavam $41 \%$ da população ou dos eleitores do município. 
Tabela 1

População de Campos dos Goytacazes segundo Censo de 1872

\begin{tabular}{l|c|c}
\hline \multirow{2}{*}{} & \multicolumn{2}{|c}{ Habitantes } \\
\cline { 2 - 3 } & $\mathbf{N}-$ & $\mathbf{( \% )}$ \\
\hline Município de Campos & 88.825 & 100,0 \\
\hline Freguesia de São Salvador & 19.520 & 22,0 \\
Freguesia de São Gonçalo & 10.998 & 12,4 \\
Freguesia de Natividade & 5.635 & 6,3 \\
\hline Total das freguesias analisadas & $\mathbf{3 6 . 1 5 3}$ & $\mathbf{4 0 , 7}$ \\
\hline
\end{tabular}

Fonte: Elaboração própria, a partir de Alvarenga (1884).

Tabela 2

Percentual de Eleitores

Campos dos Goytacazes - 1876

\begin{tabular}{l|c|c}
\hline \multirow{2}{*}{} & \multicolumn{2}{|c}{ Eleitores } \\
\cline { 2 - 3 } & $\mathbf{N}-$ & $\mathbf{( \% )}$ \\
\hline Município de Campos & 206 & 100,0 \\
\hline Freguesia de São Salvador & 46 & 22,3 \\
Freguesia de São Gonçalo & 27 & 13,1 \\
Freguesia de Natividade & 13 & 6,3 \\
\hline Total de eleitores das freguesias analisadas & $\mathbf{8 6}$ & $\mathbf{4 1 , 7}$ \\
\hline
\end{tabular}

Fonte: Elaboração própria, a partir de Relatório do Presidente da Província do Rio de Janeiro.

As informações consignadas nas listas de qualificação apresentam alguns problemas, em parte resultantes das mazelas do processo de qualificação. Assim, por exemplo, na lista referente a São Salvador, 99\% dos votantes estão registrados com renda presumida (e não renda comprovada) e, na paróquia de Natividade, há uma enorme concentração dos votantes na faixa de renda entre 200 mil réis e $400 \mathrm{mil}$ réis. Estes fatos são indicativos de que os processos de qualificação padeciam de pouco rigor. Mas, a despeito de suas limitações, os documentos analisados contêm dados importantes sobre a sociedade da época e, como sabido, têm sido utilizados como base empírica para trabalhos de pesquisa que focalizam o processo eleitoral em várias regiões do país. 


\section{CAMPOS DOS GOYTACAZES: A INCLUSÃO ELEITORAL}

A partir do número de votantes registrados nas listas de qualificação encontradas, foi possível calcular os indicadores de inclusão eleitoral com relação à população de homens livres, à população livre (homens e mulheres) e à população total (livres e escravos) (Tabela 3). O resul$\operatorname{tado}^{13}$ mostrou que, para a média das três paróquias, os votantes representavam $23,0 \%$ dos homens livres, $11,4 \%$ da população livre e $6,9 \%$ da população total (Tabela 4). Este último valor é bem inferior ao estimado por Carvalho (1988) para o Brasil da década de 1870: 10,8\% de votantes da população total. A menor taxa de inclusão verificada para a média das paróquias focalizadas explica-se, muito provavelmente, pelo maior peso da população escrava na região, relativamente ao quadro encontrado no país ${ }^{14}$. Mesmo assim, a taxa de inclusão da média das paróquias está em um patamar próximo ou superior ao verificado para alguns países da Europa Ocidental no mesmo período (ver nota 5).

Vale registrar que, na região, independentemente da referência considerada (homens livres, população livre ou população total), a taxa de inclusão tende a ser maior nas paróquias menos urbanizadas. Assim, a participação dos votantes na população total de São Salvador estava em 6,1\%, enquanto em São Gonçalo e em Natividade atingia a ordem de $6,5 \%$ e $10,7 \%$, respectivamente.

Por fim, é importante registrar que o número de votantes elegíveis como parcela da população total estava em 3,9\% em São Salvador, 1,6\% em São Gonçalo, 2,5\% em Natividade e em 3,0\% para a média das três paróquias. Estes valores, significativamente inferiores às taxas de inclusão antes comentadas, estão em consonância com a legislação eleitoral do período, mais severa no que se refere ao direito de ser eleito do que em relação ao direito de voto.

\section{CAMPOS DOS GOYTACAZES: 0 PERFIL DA POPULAÇÃO QUALIFICADA}

O exame das três listas de qualificação referentes às paróquias de São Salvador (1876), São Gonçalo (1878) e Natividade (1878), quando a eleição ainda seguia o sistema de eleições indiretas, permite traçar um perfil do universo de votantes do município (idade, renda, instrução e atividade profissional), caracterizar diferenças e semelhanças entre as áreas rurais e urbana e comparar o perfil encontrado com o 
Tabela 3

População e Número de Votantes

\begin{tabular}{l|c|c|c|c|c|c|c}
\hline \multirow{2}{*}{ Paróquias } & \multicolumn{3}{|c|}{ População (n⿳⺈⿴囗十一 } & \multicolumn{2}{c}{ Votantes (nos absolutos) } \\
\cline { 2 - 9 } & $\begin{array}{c}\text { Homens } \\
\text { Livres }\end{array}$ & $\begin{array}{c}\text { Mulheres } \\
\text { Livres }\end{array}$ & $\begin{array}{c}\text { Escra- } \\
\text { vos }\end{array}$ & Total & $\begin{array}{c}\text { Não Ele- } \\
\text { gíveis }\end{array}$ & Elegíveis & Total \\
\hline Urbana & & & & & & & \\
São Salvador & 5.572 & 5.939 & 8.009 & 19.520 & 433 & 761 & 1.194 \\
\hline Rurais & & & & & & & \\
São Gonçalo & 3.246 & 3.502 & 4.250 & 10.998 & 538 & 173 & 711 \\
Natividade & 2.071 & 1.732 & 1.832 & 5.635 & 462 & 141 & 603 \\
\hline Total & $\mathbf{1 0 . 8 8 9}$ & $\mathbf{1 1 . 1 7 3}$ & $\mathbf{1 4 . 0 9 1}$ & $\mathbf{3 6 . 1 5 3}$ & $\mathbf{1 . 4 3 3}$ & $\mathbf{1 . 0 7 5}$ & $\mathbf{2 . 5 0 8}$ \\
\hline
\end{tabular}

Fontes: Censo de 1872, para a população, e Listas de Qualificação - São Salvador (1876), São Gonçalo (1878) e Natividade (1878) -, para votantes.

Tabela 4

Inclusão Eleitoral - Campos dos Goytacazes

\begin{tabular}{|c|c|c|c|}
\hline \multirow{2}{*}{ Paróquias } & \multicolumn{3}{|c|}{ Votantes sobre População de Homens Livres (\%) } \\
\hline & Não Elegíveis & Elegíveis & Total \\
\hline \multicolumn{4}{|l|}{ Urbana } \\
\hline $\begin{array}{l}\text { Rurais } \\
\text { São Gonçalo } \\
\text { Natividade } \\
\end{array}$ & $\begin{array}{l}16,6 \\
22,3\end{array}$ & $\begin{array}{l}5,3 \\
6,8 \\
\end{array}$ & $\begin{array}{l}21,9 \\
29,1 \\
\end{array}$ \\
\hline Média & 13,2 & 9,9 & 23,0 \\
\hline \multirow{2}{*}{ Paróquias } & \multicolumn{3}{|c|}{ Votantes sobre População Livre: Homens e Mulheres (\%) } \\
\hline & Não Elegíveis & Elegíveis & Total \\
\hline $\begin{array}{l}\text { Urbana } \\
\text { São Salvador }\end{array}$ & 3,8 & 6,6 & 10,4 \\
\hline $\begin{array}{l}\text { Rurais } \\
\text { São Gonçalo } \\
\text { Natividade } \\
\end{array}$ & $\begin{array}{c}8,0 \\
12,1 \\
\end{array}$ & $\begin{array}{l}2,6 \\
3,7\end{array}$ & $\begin{array}{l}10,5 \\
15,9 \\
\end{array}$ \\
\hline Média & 6,5 & 4,9 & 11,4 \\
\hline \multirow{2}{*}{ Paróquias } & \multicolumn{3}{|c|}{ Votantes sobre População Total: Livres e Escravos (\%) } \\
\hline & Não Elegíveis & Elegíveis & Total \\
\hline $\begin{array}{l}\text { Urbana } \\
\text { São Salvador }\end{array}$ & 2,2 & 3,9 & 6,1 \\
\hline $\begin{array}{l}\text { Rurais } \\
\text { São Gonçalo } \\
\text { Natividade }\end{array}$ & $\begin{array}{l}4,9 \\
8,2 \\
\end{array}$ & $\begin{array}{l}1,6 \\
2,5\end{array}$ & $\begin{array}{c}6,5 \\
10,7 \\
\end{array}$ \\
\hline Média & 4,0 & 3,0 & 6,9 \\
\hline
\end{tabular}

Fonte: Elaboração própria, a partir dos dados da Tabela 3. 
dos eleitores de São Paulo desenhado em estudo sobre o tema (Klein, 1995). Este é o objetivo das considerações que se seguem. Vale sublinhar que este artigo lida apenas com o universo dos votantes (elegíveis e não elegíveis), constituído basicamente por homens livres, maiores de $25 \operatorname{anos}^{15}$ e com alguma renda. Como se sabe, afora algumas restrições previstas em lei, a renda e a idade constituíam os grandes obstáculos ao direito de voto dos homens livres, enquanto mulheres e escravos estavam por princípio excluídos.

a) Idade - A análise das diversas faixas etárias dos qualificados da paróquia urbana e das duas rurais do Município de Campos dos Goytacazes evidencia que a pirâmide por faixa de idade dos eleitores segue, provavelmente, a pirâmide de idade dos habitantes (homens livres) ${ }^{16}$. Isto confirmaria a hipótese de Klein (1995:531) de que "os eleitores não eram uma oligarquia limitada pela idade, mas espelhavam perfeitamente a estrutura de idade da população a que pertenciam". No caso de Campos, há uma faixa fora da tendência anterior: os qualificados entre 25 e 29 anos nas paróquias rurais a parecem como porcentagem muito menor se comparados aos de 30-34 (Gráfico 1). Uma explicação para este fato está no pressuposto de que na zona rural os homens mais jovens demoravam mais a constituir-se como uma unidade de renda autônoma, o que atrasava sua entrada no universo dos votantes. Outra hipótese seria a ocorrência no período de uma migração campo-cidade da população masculina, concentrada na faixa de 25 a 29 anos. A idade média dos homens urbanos (São Salvador) qualificados para votar era de 41 anos e a dos rurais, de 42 anos (43 em Natividade e 41 em São Gonçalo). Estes números estão muito próximos dos encontrados por Klein para São Paulo, onde este autor obteve uma idade média de 40 anos para áreas urbanas e rurais.

b) Idade e Renda-Quando se relaciona idade e renda anual, percebe-se que os pobres representavam uma expressiva parcela do total dos votantes, mesmo nas faixas de idade mais altas. Entretanto, no universo dos votantes, há uma correlação significativa entre idade e renda, isto é, nas faixas mais altas de idade a participação de pobres tende a diminuir. A Tabela 5 ilustra bem este ponto ao revelar a participação dos qualificados mais ricos e mais pobres ${ }^{17}$ discriminada por faixas de idade. 
Gráfico 1

Campos dos Goytacazes - Distribuição dos Qualificados

Urbanos e Rurais por Faixa de Idade (\%)

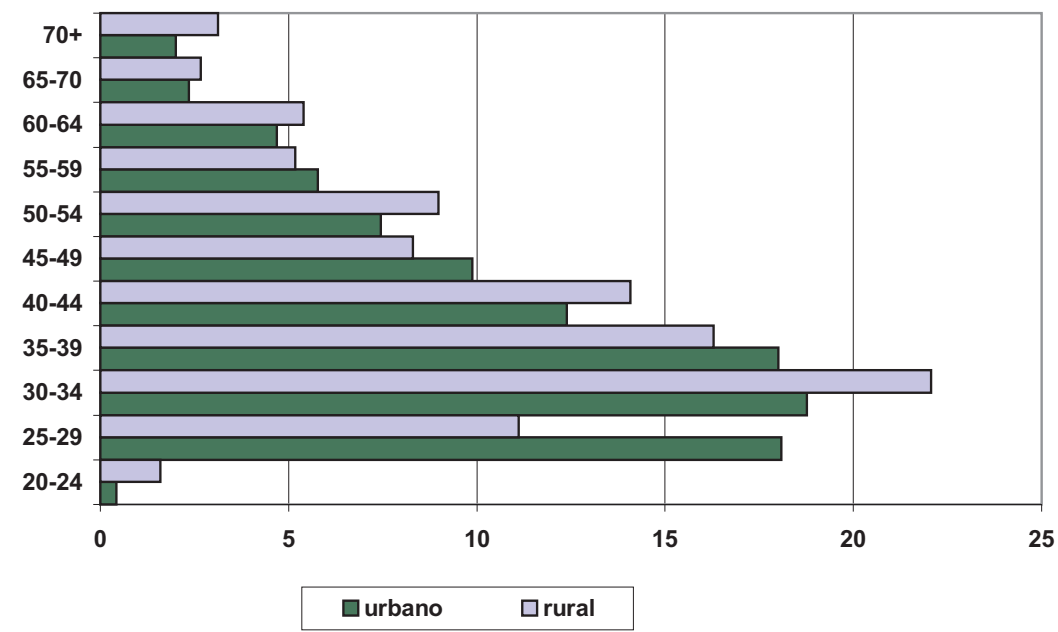

Fonte: Elaboração própria, a partir das listas de qualificação de votantes (São Salvador, 1876; São Gonçalo, 1878; Natividade, 1878).

Tabela 5

Qualificados Totais (São Salvador, São Gonçalo e Natividade)

Participação dos mais Pobres e mais Ricos* nos Qualificados

\begin{tabular}{c|c|c}
\multicolumn{3}{c}{ por Faixas de Idade } \\
\hline Faixa de Idade & Mais Pobres (\%) & Mais Ricos (\%) \\
\hline$<24$ & 92,3 & 7,7 \\
$25-29$ & 80,7 & 19,3 \\
$30-34$ & 84,0 & 16,0 \\
$35-39$ & 74,6 & 25,4 \\
$40-44$ & 78,1 & 21,9 \\
$45-49$ & 73,5 & 26,5 \\
$50-54$ & 72,6 & 27,4 \\
$55-59$ & 70,6 & 29,4 \\
$60-64$ & 69,3 & 30,7 \\
$65-69$ & 62,3 & 37,7 \\
$70+$ & 64,2 & 35,8 \\
\hline
\end{tabular}

Fonte: Elaboração própria, a partir das listas de qualificação de votantes (São Salvador, 1876; São Gonçalo, 1878; Natividade, 1878).

* Mais pobres: qualificados com menos de 600 mil réis de renda anual; mais ricos com 600 mil réis ou mais. 
As informações da Tabela 5 permitem concluir que a inserção de pobres nos qualificados decresce com a idade, permanecendo, contudo, muito expressiva em todas as faixas etárias. No pior dos casos (60 anos ou mais), essa participação fica em torno de dois terços dos qualificados, circunstância indicativa de que homens livres e pobres tomavam parte significativa no processo eleitoral.

Se combinarmos os dados do Gráfico 1 com aqueles da Tabela 5, podemos ter como explicação, para a menor participação de pobres nas faixas etárias mais altas da população qualificada, a hipótese de que a expectativa de vida dos mais pobres era, no período, menor que a dos mais ricos. Haveria, relativamente, menos pobres nos qualificados de mais idade porque haveria proporcionalmente menos pobres na população mais longeva ${ }^{18}$.

c) Distribuição da Renda - A análise das informações sobre renda indica que os cidadãos qualificados da zona urbana eram, em média, mais ricos do que os da área rural. A renda média dos qualificados na paróquia de São Salvador, situada na sede do município, estava em 1.011 mil réis anuais, bem mais elevada do que a dos votantes de Natividade (247 mil réis anuais) e a dos de São Gonçalo (657 mil réis anuais). $\mathrm{O}$ exame comparativo da distribuição de renda da população votante das três paróquias foi realizado utilizando-se o índice de Gini ${ }^{19}$, instrumento adequado para avaliar diferenças de concentração de renda intra-regionais. É importante lembrar que esse exercício engloba aqui apenas o universo dos qualificados. O resultado encontrado foi o seguinte: a população votante da paróquia de São Salvador possui um Gini de 0,5410, a de São Gonçalo de 0,6173 e a de Natividade de 0,1442 . São Gonçalo, que constitui uma freguesia rural, com sede situada mais próxima da cidade, revela a pior distribuição de renda da população qualificada, um resultado que a aproxima da freguesia de São Salvador, genuinamente urbana. Natividade, a menos urbanizada, é a que apresenta melhor distribuição de renda no grupo dos votantes. Sua população qualificada, mais pobre e com melhor distribuição de renda vive uma espécie de igualdade na pobreza ${ }^{20}$. É interessante registrar que os índices de São Salvador e de São Gonçalo são próximos aos encontrados por Klein para a São Paulo urbana e o de Natividade para a São Paulo rural.

A Tabela 6 mostra a renda acumulada da população votante nas três freguesias e sua leitura permite identificar, por outra via, que o grupo 
de qualificados de Natividade era o que possuía a melhor distribuição de renda. Os seus $10 \%$ mais pobres detinham $8,1 \%$ da renda, enquanto os de São Gonçalo se apropriavam de 3,0\% e os de São Salvador de 2,0\%. Lendo ao inverso, em Natividade, os $10 \%$ votantes mais ricos respondiam por $16,2 \%$ da renda total dos votantes, proporção que atinge a ordem de 66,6\% em São Gonçalo e de 42,4\% em São Salvador.

Tabela 6

Qualificados - Renda Apropriada por Decis Acumulados em Ordem de Pobreza

\begin{tabular}{c|c|c|c|c|c}
\hline \multicolumn{2}{c|}{ Natividade } & \multicolumn{2}{c|}{ São Gonçalo } & \multicolumn{2}{c}{ São Salvador } \\
\hline $\begin{array}{c}\text { Decis Acu- } \\
\text { mulados }\end{array}$ & $\begin{array}{c}\text { \% Renda } \\
\text { Acumulada }\end{array}$ & $\begin{array}{c}\text { Decis Acu- } \\
\text { mulados }\end{array}$ & $\begin{array}{c}\text { \% Renda } \\
\text { Acumulada }\end{array}$ & $\begin{array}{c}\text { Decis Acu- } \\
\text { mulados }\end{array}$ & $\begin{array}{c}\text { \% Renda } \\
\text { Acumulada }\end{array}$ \\
\hline 10 & 8,1 & 10 & 3,0 & 10 & 2,0 \\
20 & 16,2 & 20 & 5,9 & 20 & 4,7 \\
30 & 24,3 & 30 & 8,9 & 30 & 7,6 \\
40 & 32,3 & 40 & 11,8 & 40 & 11,0 \\
50 & 40,4 & 50 & 14,8 & 50 & 14,9 \\
60 & 48,5 & 60 & 17,8 & 60 & 19,6 \\
70 & 56,6 & 70 & 20,7 & 70 & 26,0 \\
80 & 67,7 & 80 & 25,0 & 80 & 36,1 \\
90 & 83,8 & 90 & 33,4 & 90 & 57,6 \\
100 & 100,0 & 100 & 100,0 & 100 & 100,0 \\
\hline
\end{tabular}

Fonte: Elaboração própria, a partir das listas de qualificação de votantes (São Salvador, 1876; São Gonçalo, 1878; Natividade, 1878).

Uma outra forma de abordar a concentração de renda na população votante das três freguesias está descrita na Tabela 7. Pela leitura de seus números, pode-se constatar que a maior parte dos eleitores das duas paróquias rurais recebe renda mínima, ou seja, até 200 mil réis (em torno de $76 \%$ em Natividade e em São Gonçalo); em São Salvador, essa porcentagem é de 12,7\%. A melhor distribuição de renda verificada para o grupo de votantes de Natividade é revelada, ainda, pelo fato de seus qualificados de renda mínima (76,3\% do total) apropriarem-se de $61,7 \%$ da renda anual do total dos qualificados da paróquia. Em São Gonçalo e em São Salvador, essa relação é de 75,7\% para $22,4 \%$ e de $12,7 \%$ para $2,5 \%$, respectivamente. 
A Experiência Eleitoral em Campos dos Goytacazes (1870-1889)...

Tabela 7

Distribuição dos Eleitores pelos Valores de Rendas Anuais (renda em mil réis)

\begin{tabular}{|c|c|c|c|}
\hline \multirow{2}{*}{ Paróquias } & \multirow{2}{*}{ Renda Anual } & \multicolumn{2}{|c|}{$\%$ Acumulada } \\
\hline & & de qualificados & de rendas \\
\hline \multirow[t]{3}{*}{ Natividade } & até 200 & 76,3 & 61,7 \\
\hline & até 300 & 76,6 & 62,1 \\
\hline & até 400 & 100,0 & 100,0 \\
\hline \multirow[t]{18}{*}{ São Gonçalo } & até 200 & 75,7 & 22,4 \\
\hline & até 400 & 81,4 & 25,8 \\
\hline & até 500 & 82,0 & 26,3 \\
\hline & até 600 & 89,7 & 33,1 \\
\hline & até 800 & 90,2 & 33,6 \\
\hline & até 1.000 & 92,5 & 37,2 \\
\hline & até 1.400 & 92,7 & 37,5 \\
\hline & até 1.600 & 92,8 & 37,8 \\
\hline & até 2.000 & 95,6 & 46,1 \\
\hline & até 3.000 & 96,1 & 48,0 \\
\hline & até 4.400 & 96,2 & 48,9 \\
\hline & até 5.000 & 97,2 & 56,2 \\
\hline & até 6.000 & 97,9 & 62,5 \\
\hline & até 8.000 & 98,7 & 72,5 \\
\hline & até 10.000 & 98,9 & 74,6 \\
\hline & até 12.000 & 99,7 & 89,6 \\
\hline & até 20.000 & 99,9 & 93,7 \\
\hline & até 30.000 & 100,0 & 100,0 \\
\hline \multirow[t]{21}{*}{ São Salvador } & até 200 & 12,7 & 2,5 \\
\hline & até 300 & 36,2 & 9,4 \\
\hline & até 360 & 36,2 & 9,5 \\
\hline & até 400 & 52,1 & 15,7 \\
\hline & até 500 & 61,8 & 20,5 \\
\hline & até 600 & 67,7 & 24,0 \\
\hline & até 700 & 67,8 & 24,1 \\
\hline & até 800 & 69,5 & 25,4 \\
\hline & até 1.000 & 78,9 & 34,7 \\
\hline & até 1.200 & 79,7 & 35,6 \\
\hline & até 1.400 & 79,9 & 35,9 \\
\hline & até 1.500 & 80,7 & 37,0 \\
\hline & até 1.600 & 80,8 & 37,3 \\
\hline & até 2.000 & 87,9 & 51,2 \\
\hline & até 3.000 & 90,8 & 59,8 \\
\hline & até 3.600 & 90,9 & 60,1 \\
\hline & até 4.000 & 98,2 & 88,9 \\
\hline & até 5.000 & 99,1 & 93,4 \\
\hline & até 6.000 & 99,5 & 95,9 \\
\hline & até 8.000 & 99,9 & 99,2 \\
\hline & até 10.000 & 100,0 & 100,0 \\
\hline
\end{tabular}

Fonte: Elaboração própria, a partir das listas de qualificação de votantes (São Salvador, 1876; São Gonçalo, 1878; Natividade, 1878). 
Utilizando o corte de 600 mil réis para caracterizar o segmento mais rico e o mais pobre da população qualificada para votar ${ }^{21}$, os números da Tabela 7 revelam ainda que, em São Gonçalo, os mais pobres eram $82,0 \%$ dos qualificados, que se apropriavam de $26,3 \%$ da renda anual do total de qualificados da paróquia; os mais ricos, por seu lado, representavam 18,0\% dos qualificados, que se apropriavam de 73,7\% da renda. Em São Salvador, os mais pobres representavam $61,8 \%$ dos qualificados, que se apossavam de $20,5 \%$ da renda global dos qualificados da paróquia, enquanto os mais ricos perfaziam $38,2 \%$ dos qualificados, que detinham $79,5 \%$ da renda. Pelo critério utilizado, não havia ricos em Natividade.

As considerações anteriores, salientando o peso dos mais pobres no grupo de votantes e a distribuição de renda neste grupo nas três paróquias, evidenciam uma participação não desprezível de pobres no universo dos qualificados. Vale lembrar que, uma vez que o corte de renda era um dos critérios utilizados para definir o universo de votantes, é de se esperar que os pobres estejam sub-representados ali, isto é, que sua participação neste conjunto seja menor que na população total. Contudo, isto não invalida a constatação de que a população mais pobre estava presente na composição do universo de votantes em uma medida relevante. Representava 61,8\% dos votantes de São Salvador, 100,0\% dos votantes de Natividade e $82,0 \%$ dos de São Gonçalo.

A verificação de uma alta concentração de renda no universo dos qualificados parece indicar que as sociedades das paróquias analisadas conviviam com altos índices de concentração de renda. Entretanto, o grupo de votantes não pode ser interpretado como uma amostra representativa da população total, dados os critérios de sua definição (cortes por renda, gênero e idade). Discutir em que medida a distribuição de renda entre os qualificados refletia a distribuição de renda da população total demandaria exercícios e testes estatísticos não realizados em função da inexistência de dados suficientes para fundamentá-los.

d) Renda e Escolaridade - Uma questão interessante tem a ver com a avaliação do peso da presença dos analfabetos entre os qualificados, grupo marcado por alto grau de concentração de renda. A Tabela 8 mostra que os analfabetos representavam parcela importante dos vo- 
tantes não elegíveis (37\% no total das três paróquias) e uma pequena proporção dos votantes elegíveis (4\% no total das três paróquias).

Tabela 8

Distribuição dos Qualificados segundo o Grau de Instrução

\begin{tabular}{c|c|c|c|c|c|c}
\hline \multirow{2}{*}{ Paróquias } & \multicolumn{2}{|c|}{$\begin{array}{c}\text { Votantes (não elegí- } \\
\text { veis) }\end{array}$} & \multicolumn{2}{c|}{ Votantes (elegíveis) } & \multicolumn{2}{c}{$\begin{array}{c}\text { Total dos Qualifi- } \\
\text { cados }\end{array}$} \\
\cline { 2 - 7 } & $\mathbf{N}^{\mathbf{0}}$ & $\begin{array}{c}\text { Participa- } \\
\text { ção } \\
\mathbf{( \% )}\end{array}$ & $\mathbf{N}^{\mathbf{0}}$ & $\begin{array}{c}\text { Participa- } \\
\text { ção } \\
\mathbf{( \% )}\end{array}$ & $\mathbf{N}^{\mathbf{0}}$ & $\begin{array}{c}\text { Partici- } \\
\text { pação } \\
\mathbf{( \% )}\end{array}$ \\
\hline A- Natividade & 462 & 100 & 141 & 100 & 603 & 100 \\
\hline Alfabetizados & 209 & 45 & 115 & 82 & 324 & 54 \\
Analfabetos & 120 & 26 & 5 & 3 & 125 & 21 \\
Sem informação & 133 & 29 & 21 & 15 & 154 & 25 \\
\hline B-São Gonçalo & 538 & 100 & 173 & 100 & 711 & 100 \\
\hline Alfabetizados & 216 & 40 & 153 & 88 & 369 & 52 \\
Analfabetos & 320 & 59 & 20 & 12 & 340 & 48 \\
Sem informação & 2 & 1 & 0 & 0 & 2 & 0 \\
\hline C-São Salvador & 433 & 100 & 761 & 100 & 1.194 & 100 \\
\hline Alfabetizados & 348 & 81 & 741 & 98 & 1.089 & 91 \\
Analfabetos & 84 & 19 & 18 & 2 & 102 & 9 \\
Sem informação & 1 & 0 & 2 & 0 & 3 & 0 \\
\hline Total (A+B+C) & $\mathbf{1 . 4 3 3}$ & $\mathbf{1 0 0}$ & $\mathbf{1 . 0 7 5}$ & $\mathbf{1 0 0}$ & $\mathbf{2 . 5 0 8}$ & $\mathbf{1 0 0}$ \\
\hline Alfabetizados & 773 & 54 & 1.009 & 94 & 1.782 & 71 \\
Analfabetos & 524 & 37 & 43 & 4 & 567 & 23 \\
Sem informação & 136 & 9 & 23 & 2 & 159 & 6 \\
\hline
\end{tabular}

Fonte: Elaboração própria, a partir das listas de qualificação de votantes (São Salvador, 1876; São Gonçalo, 1878; Natividade, 1878).

Nas paróquias rurais, a participação dos analfabetos entre os votantes era expressiva. Em Natividade, representavam $21 \%$ dos qualificados, proporção que aumenta para $46 \%$ se considerarmos como analfabetos os qualificados a respeito dos quais não há informação sobre escolaridade $^{22}$. Em São Gonçalo, representavam $48 \%$ dos qualificados; já em São Salvador, formavam a menor parcela dos qualificados (9\%). Estes números indicam que a participação dos analfabetos no grupo de votantes tendia a ser mais expressiva nas paróquias rurais. De fato, os dados do Município Neutro (a Corte) apontam nessa direção. Por exemplo, a paróquia da Candelária não possuía nenhum analfabeto 
alistado em 1876, a da Glória tinha 19,1\%, enquanto nas freguesias rurais de Santa Cruz, Guaratiba e Jacarepaguá os percentuais eram bastante altos: 57,3\%, 52,3\% e 48,35\%, respectivamente (Nicolau, 2002).

Comparando-se a média das três paróquias de Campos (23\%) com as calculadas por Klein para São Paulo (39\%) e por Cardoso para Curitiba (46\%), verifica-se que os analfabetos constituíam uma proporção maior dos votantes nestas duas últimas regiões. Os dados apresentados pelas listas de qualificação do Município de Campos confirmam as evidências encontradas por Klein para São Paulo: a presença de um contingente importante de analfabetos entre os votantes e a tendência de o seu peso ser maior nas paróquias rurais (Natividade e São Gonçalo) do que na urbana (São Salvador).

A análise das listas de qualificação permite estabelecer ainda uma relação clara entre o grau de instrução e a renda dos qualificados. Quanto mais pobre o votante, maior a chance de ele ser analfabeto. A Tabela 9 revela que, em todas as paróquias, a renda média dos analfabetos votantes era menor que a dos alfabetizados. Klein obtém para São Paulo um resultado adicional: os analfabetos votantes eram mais pobres que os alfabetizados, porém essa diferença era mais acentuada nas paróquias urbanas. No caso de Campos, se considerarmos São Gonçalo uma freguesia rural, tal não se verifica, visto que a diferença encontrada para esta paróquia é maior que aquela constatada na paróquia urbana de São Salvador. Em Natividade, a evidência observada por Klein confirma-se: menor diferencial de renda entre alfabetizados votantes e analfabetos votantes nas paróquias rurais.

Tabela 9

Renda Média dos Qualificados por Escolaridade (em mil réis)

\begin{tabular}{l|c|c|c|c}
\hline \multirow{2}{*}{ Paróquias } & \multicolumn{3}{|c}{ Qualificados } \\
\cline { 2 - 5 } & Alfabetizados & Analfabetos & $\begin{array}{c}\text { Sem Infor- } \\
\text { mação }\end{array}$ & Total \\
\hline A - Natividade & 272 & 208 & 227 & 247 \\
B - São Gonçalo & 1.066 & 254 & 200 & 675 \\
C - São Salvador & 1.079 & 306 & 333 & 1.011 \\
\hline Total (A+B+C) & $\mathbf{9 3 0}$ & $\mathbf{2 5 3}$ & $\mathbf{2 2 9}$ & $\mathbf{7 3 2}$ \\
\hline
\end{tabular}

Fonte: Elaboração própria, a partir das listas de qualificação de votantes (São Salvador, 1876; São Gonçalo, 1878; Natividade, 1878). 
Outra maneira de examinar a relação entre escolaridade e renda é calculando a participação dos analfabetos entre os qualificados mais ricos e entre os qualificados mais pobres. Considerando as três paróquias em conjunto, entre os qualificados mais pobres, $28,8 \%$ eram analfabetos; já no grupo dos qualificados mais ricos, os analfabetos representavam apenas 2,1\% (ver Tabela 10).

Tabela 10

Município de Campos dos Goytacazes

Qualificados: Instrução segundo a Faixa de Renda

\begin{tabular}{|c|c|c|c|c|c|c|}
\hline \multirow[b]{2}{*}{ Faixa de Renda } & \multicolumn{2}{|c|}{$\begin{array}{c}\text { (a) } 600 \text { mil réis ou } \\
\text { mais }\end{array}$} & \multicolumn{2}{|c|}{$\begin{array}{c}\text { (b) Menos de } 600 \\
\text { mil réis }\end{array}$} & \multicolumn{2}{|c|}{ Total $(a+b)$} \\
\hline & $\mathrm{N}^{\mathrm{o}}$ & $\begin{array}{c}\text { Partici- } \\
\text { pação } \\
(\%)\end{array}$ & $\mathrm{N}^{\mathrm{o}}$ & $\begin{array}{c}\text { Partici- } \\
\text { pação } \\
(\%)\end{array}$ & $\mathrm{N}^{\mathrm{o}}$ & $\begin{array}{c}\text { Partici- } \\
\text { pação } \\
(\%)\end{array}$ \\
\hline A - São Salvador & 455 & 100,0 & 739 & 100,0 & 1.194 & 100,0 \\
\hline Alfabetizados & 454 & 99,8 & 635 & 85,9 & 1.089 & 91,2 \\
\hline Analfabetos & 1 & 0,2 & 101 & 13,7 & 102 & 8,5 \\
\hline Sem informação & 0 & 0,0 & 3 & 0,4 & 3 & 0,3 \\
\hline B - Natividade & 0 & 0,0 & 603 & 100 & 603 & 100 \\
\hline Alfabetizados & 0 & 0,0 & 324 & 53,7 & 324 & 53,7 \\
\hline Analfabetos & 0 & 0,0 & 125 & 20,7 & 125 & 20,7 \\
\hline Sem informação & 0 & 0,0 & 154 & 25,5 & 154 & 25,5 \\
\hline C - São Gonçalo & 128 & 100,0 & 583 & 100,0 & 711 & 100,0 \\
\hline Alfabetizados & 117 & 91,4 & 252 & 43,2 & 369 & 51,9 \\
\hline Analfabetos & 11 & 8,6 & 329 & 56,4 & 340 & 47,8 \\
\hline Sem informação & 0 & 0,0 & 2 & 0,3 & 2 & 0,3 \\
\hline Total $(A+B+C)$ & 583 & 100,0 & 1.925 & 100,0 & 2.508 & 100,0 \\
\hline Alfabetizados & 571 & 97,9 & 1.211 & 62,9 & 1.782 & 71,1 \\
\hline Analfabetos & 12 & 2,1 & 555 & 28,8 & 567 & 22,6 \\
\hline Sem informação & 0 & 0,0 & 159 & 8,3 & 159 & 6,3 \\
\hline
\end{tabular}

Fonte: Elaboração própria, a partir das listas de qualificação de votantes.

A relação positiva entre renda e alfabetização encontrada no grupo dos votantes das paróquias analisadas revela que a pequena participação de analfabetos no subgrupo dos votantes elegíveis (Tabela 8) se explica pelo corte de renda que define quem pode ser eleito. 
Uma vez que a legislação eleitoral excluía escravos, mulheres e homens livres com renda inferior a 200 mil réis, é esperado que a população analfabeta estivesse sub-representada no universo de votantes, isto é, constituísse uma parcela relativa dos votantes menor que a proporção de analfabetos na população total. Isto porque a taxa de alfabetização dos escravos era próxima a zero ${ }^{23}$, a das mulheres livres menor que a dos homens livres ${ }^{24}$ e a taxa de alfabetização neste último grupo tendia a ser maior nos estratos superiores de renda. De fato, segundo os dados do Censo de 1872, a taxa de analfabetismo da população total do Município de Campos dos Goytacazes era de 88,5\%. Este número, comparado à taxa média de analfabetismo da população votante das três paróquias (cerca de 23,0\% - Tabela 8), confirma a tendência esperada, qual seja, a de sub-representação de analfabetos no universo de votantes.

e) Ocupação Profissional - Como sabido, as listas de qualificação de votantes registram a profissão dos qualificados, o que torna possível conhecer a estrutura ocupacional do universo de votantes. Para realizar este exercício, foi necessário agrupar as diversas profissões em algumas categorias, o que constituiu um trabalho bastante complexo, tendo em vista as informações limitadas sobre a natureza de cada uma delas. As reflexões contidas no trabalho de Maria Yedda Linhares (1979), a observação dos livros de posse dos cargos da Câmara Municipal e de documentos de época serviram para orientar a classificação realizada neste trabalho. As diversas ocupações contidas nas listas foram então reunidas em conjuntos profissionais descritos na Tabela 11, que registra a distribuição da população qualificada por grupo ocupacional. Como se pode observar, nas paróquias rurais, cerca de $75 \%$ dos qualificados estão ocupados na agricultura, pecuária, atividades extrativas ou são lavradores. Na paróquia urbana, a maior concentração está no agrupamento dos artesãos / ofícios urbanos e no de comércio e serviços que, em conjunto, abrigam $53 \%$ do total dos qualificados. Vale sublinhar que entre os votantes da paróquia urbana está presente um grupo expressivo de rentistas (proprietários imobiliários urbanos e detentores de capital dinheiro), que representam $11,5 \%$ dos qualificados.

f) Ocupação Profissional e Renda - A Tabela 12 registra a renda anual média dos diversos grupos ocupacionais que compõem o universo de votantes. Dentre estes, o dos trabalhadores ligados à agricultura, pecuária e atividades extrativas aparece como o mais pobre. Sua renda 
Tabela 11

Total dos Votantes nas Paróquias Analisadas

Distribuição por Grupos Ocupacionais

\begin{tabular}{l|c|c|c}
\hline Grupo Ocupacional & Rurais* & $\begin{array}{c}\text { Urba- } \\
\text { na** }^{* *}\end{array}$ & Total \\
\hline Agricultura, pecuária e atividades extrativas & 35,1 & 0,7 & 18,7 \\
Lavradores $^{25}$ & 40,3 & 16,2 & 28,8 \\
Artesão/ofícios urbanos & 11,1 & 21,7 & 16,1 \\
Comércio e serviços & 4,9 & 31,1 & 17,4 \\
Profissionais liberais & 0,7 & 6,9 & 3,6 \\
Proprietários & 4,9 & 17,0 & 10,6 \\
$\quad$ fazendeiros & 4,8 & 5,5 & 5,1 \\
$\quad$ demais (propriedades urbanas e capital dinheiro) & 0,1 & 11,5 & 5,5 \\
Setor público & 1,5 & 5,2 & 3,3 \\
Não identificado & 1,5 & 1,3 & 1,4 \\
\hline Total Geral & $\mathbf{1 0 0 , 0}$ & $\mathbf{1 0 0 , 0}$ & $\mathbf{1 0 0 , 0}$ \\
\hline
\end{tabular}

Fonte: Elaboração própria, a partir das listas de qualificação de votantes (São Salvador, 1876; São Gonçalo, 1878; Natividade, 1878).

* Natividade e São Gonçalo.

** São Salvador.

média anual (249 mil réis) é menor que a renda média de todos os demais agrupamentos, e somente $6,6 \%$ de seus trabalhadores registravam renda anual igual ou superior a 600 mil réis. Em uma escala de pobreza, segue-se ao grupo dos lavradores aquele dos artesãos e ofícios urbanos e o de trabalhadores ligados ao comércio e aos serviços.

O grupo de votantes mais rico é o dos fazendeiros, seguido do dos profissionais liberais. Estão, também, nos estratos superiores de renda o grupo dos demais proprietários, cuja renda anual média atingia 1.808 mil réis e $96,2 \%$ de seus componentes registravam renda anual igual ou superior a 600 mil réis, e os trabalhadores do setor público (renda média anual de 1.470 mil réis e $60,7 \%$ de seus componentes com renda igual ou superior a 600 mil réis). 
Tabela 12

Total dos Votantes das Paróquias Analisadas

Grupos Ocupacionais - Renda Média e Participação dos mais Ricos por Grupo

\begin{tabular}{l|c|c}
\hline Grupos Ocupacionais & $\begin{array}{c}\text { Renda Média Anual } \\
\text { (em mil réis) }\end{array}$ & \% dos mais Ricos* \\
\hline $\begin{array}{l}\text { Agricultura, pecuária e ativida- } \\
\text { des extrativas }\end{array}$ & 249 & 6,6 \\
Artesãos/ofícios urbanos & 381 & 14,0 \\
Comércio e serviços & 606 & 30,3 \\
Lavradores & 313 & 2,6 \\
Profissionais liberais & 2.617 & 80,2 \\
Proprietários & 2.542 & 79,2 \\
$\quad$ fazendeiros & 3.326 & 81,7 \\
$\quad$ demais (propriedades urbanas & 1.808 & 96,2 \\
$\quad$ e capital dinheiro) & 1.470 & 60,7 \\
\hline
\end{tabular}

Fonte: Elaboração própria, a partir das listas de qualificação de votantes (São Salvador, 1876; São Gonçalo, 1878; Natividade, 1878).

* Profissionais com renda igual ou superior a 600 mil réis.

A Tabela 13 discrimina os qualificados das três paróquias analisadas segundo os grupos profissionais e as faixas de renda estabelecidas pela legislação eleitoral do período: 200 mil réis para ser apenas votante (não elegível); 400 mil réis para ser eleitor, juiz de paz e vereador; 800 mil réis para ser deputado; 1.600 mil réis para ser senador. A leitura de seus números revela alguns fatos interessantes, dentre os quais vale destacar:

a) como esperado, o grupo das profissões relacionadas à agricultura, pecuária e atividades extrativas tem maior peso entre os votantes nas paróquias rurais. De fato, quando somados aos lavradores, respondem por $80,1 \%$ dos qualificados de Natividade, por 71,5\% dos de São Gonçalo e por 17,6 \% dos de São Salvador;

b) em São Salvador, os artesãos/ofícios urbanos e os empregados no comércio e serviços são os grupos profissionais de maior peso no total 
de votantes. Em conjunto representam 52,3\% dos qualificados desta paróquia contra 18,7\% em São Gonçalo e 12,9\% em Natividade;

c) no universo de votantes, os grupos profissionais de trabalhadores da agricultura, pecuária e atividades extrativas, de artesãos/ofícios urbanos e de lavradores são os que apresentam renda média anual inferior a 600 mil réis (os qualificados mais pobres) e, também, os que representam a maior parcela dos qualificados mais pobres (Tabela 12). Estes grupos estão presentes no universo de votantes de todas as paróquias. Contudo, nas paróquias rurais (São Gonçalo e Natividade), os votantes que são lavradores, trabalhadores agrícolas, da pecuária e das atividades extrativas têm, em conjunto, maior peso no total dos qualificados de menor renda. Dentre os qualificados mais pobres da paróquia urbana (São Salvador), os mais numerosos são os trabalhadores do comércio e serviços;

d) considerando-se a totalidade dos qualificados das três paróquias, trabalhadores dos grupos profissionais de menor renda média (lavradores; trabalhadores agrícolas, da pecuária e de atividades extrativas; artesãos / ofícios urbanos; comércio e serviços) representam uma parcela muito expressiva do total dos qualificados: $81,1 \%$;

e) os profissionais liberais qualificados, que podem ser classificados como um grupo de renda alta (renda média anual de 2.617 mil réis e cerca de $80 \%$ com renda anual igual ou superior a 600 mil réis), estão concentrados na paróquia urbana de São Salvador. Sua participação entre os qualificados nas paróquias rurais (São Gonçalo e Natividade) é muito modesta. Entre os votantes do grupo de profissionais liberais das três paróquias, as categorias com maior peso eram os advogados (30\% desses profissionais) e os médicos (34\%);

f) os profissionais ligados ao setor público representavam 3,4\% do total dos qualificados das três paróquias. Sua participação entre os qualificados da paróquia urbana era, entretanto, mais significativa $(5,2 \%)$ do que nas paróquias rurais: Natividade $(1,7 \%)$ e São Gonçalo $(1,4 \%)$. 
Tabela 13

Qualificados - Composição por Grupos Profissionais segundo a Faixa de Renda (\%)

\begin{tabular}{|c|c|c|c|c|c|}
\hline \multirow[b]{2}{*}{ Grupos/Setores } & \multicolumn{5}{|c|}{ Faixa de Renda (em mil réis) } \\
\hline & $\begin{array}{c}1.600 \text { ou } \\
\text { Mais }\end{array}$ & $\begin{array}{c}\text { Entre } \\
1.599 \mathrm{e} \\
800\end{array}$ & $\begin{array}{c}\text { Entre } 799 \\
\text { e } 400\end{array}$ & $\begin{array}{c}\text { Entre } 399 \\
\text { e } 200\end{array}$ & Total \\
\hline \multicolumn{6}{|l|}{ A - São Salvador } \\
\hline $\begin{array}{l}\text { Trabalhadores (agric., pe- } \\
\text { cuária e ativ. extrativas) }\end{array}$ & 0,0 & 0,6 & 0,8 & 0,9 & 0,6 \\
\hline Artesãos/ofícios urbanos & 3,5 & 13,6 & 19,9 & 35,8 & 21,7 \\
\hline Comércio e serviços & 12,6 & 39,6 & 46,7 & 24,5 & 30,6 \\
\hline Lavradores & 0,4 & 2,6 & 13,3 & 31,9 & 17,0 \\
\hline Profissionais liberais & 22,1 & 8,4 & 1,9 & 1,8 & 6,6 \\
\hline Proprietários & 48,5 & 26,0 & 10,6 & 2,5 & 17,0 \\
\hline fazendeiros & 25,1 & 1,9 & 0,3 & 0,9 & 5,6 \\
\hline $\begin{array}{l}\text { demais (propriedades } \\
\text { urbanas e capital dinheiro) }\end{array}$ & 23,4 & 24,0 & 10,3 & 1,6 & 11,4 \\
\hline Setor público & 12,1 & 7,1 & 5,8 & 0,9 & 5,2 \\
\hline Não identificados & 0,9 & 1,9 & 1,1 & 1,6 & 1,4 \\
\hline Total & 100,0 & 100,0 & 100,0 & 100,0 & 100,0 \\
\hline \multicolumn{6}{|l|}{ B - São Gonçalo } \\
\hline $\begin{array}{l}\text { Trabalhadores (agric., pe- } \\
\text { cuária e ativ. extrativas) }\end{array}$ & 0,0 & 4,8 & 5,0 & 12,5 & 10,3 \\
\hline Artesãos/ofícios urbanos & 1,9 & 4,8 & 3,0 & 16,0 & 12,8 \\
\hline Comércio e serviços & 0,0 & 4,8 & 14,0 & 5,0 & 5,9 \\
\hline Lavradores & 23,1 & 33,3 & 69,0 & 64,5 & 61,2 \\
\hline Profissionais liberais & 7,7 & 0,0 & 0,0 & 0,0 & 0,6 \\
\hline Proprietários & 63,5 & 38,1 & 4,0 & 0,2 & 6,5 \\
\hline fazendeiros & 63,5 & 33,3 & 4,0 & 0,2 & 6,3 \\
\hline $\begin{array}{l}\text { demais (propriedades } \\
\text { urbanas e capital dinheiro) }\end{array}$ & 0,0 & 4,8 & 0,0 & 0,0 & 0,1 \\
\hline Setor público & 1,9 & 14,3 & 4,0 & 0,4 & 1,4 \\
\hline Não identificados & 1,9 & 0,0 & 1,0 & 1,5 & 1,4 \\
\hline Total & 100,0 & 100,0 & 100,0 & 100,0 & 100,0 \\
\hline
\end{tabular}


Tabela 13

Qualificados - Composição por Grupos Profissionais segundo a Faixa de Renda (\%) (continuação)

\begin{tabular}{l|c|c|c|c|c}
\hline \multirow{2}{*}{ Grupos/Setores } & \multicolumn{5}{|c}{ Faixa de Renda (em mil réis) } \\
\cline { 2 - 5 } & $\begin{array}{c}\mathbf{1 . 6 0 0} \text { ou } \\
\text { Mais }\end{array}$ & $\begin{array}{c}\text { Entre } \\
\mathbf{1 . 5 9 9} \text { e } \\
\mathbf{8 0 0}\end{array}$ & $\begin{array}{c}\text { Entre 799 } \\
\text { e } \mathbf{4 0 0}\end{array}$ & $\begin{array}{c}\text { Entre 399 } \\
\text { e 200 }\end{array}$ & Total \\
\hline C-Natividade & & & & & \\
\hline Trabalhadores (agric., pe- & & & & & \\
cuária e ativ. extrativas) & 0,0 & 0,0 & 0,7 & 83,8 & 64,3 \\
Artesãos/ofícios urbanos & 0,0 & 0,0 & 5,0 & 10,6 & 9,3 \\
Comércio e serviços & 0,0 & 0,0 & 7,8 & 2,4 & 3,6 \\
Lavradores & 0,0 & 0,0 & 67,4 & 0,0 & 15,8 \\
Profissionais liberais & 0,0 & 0,0 & 2,1 & 0,2 & 0,7 \\
Proprietários & 0,0 & 0,0 & 11,3 & 0,4 & 3,0 \\
fazendeiros & 0,0 & 0,0 & 11,3 & 0,4 & 3,0 \\
demais (propriedades & & & & & \\
urbanas e capital dinheiro) & 0,0 & 0,0 & 0,0 & 0,0 & 0,0 \\
Setor público & 0,0 & 0,0 & 2,8 & 1,3 & 1,7 \\
Não identificados & 0,0 & 0,0 & 2,8 & 1,3 & 1,7 \\
\hline Total & $\mathbf{0 , 0}$ & $\mathbf{0 , 0}$ & $\mathbf{1 0 0 , 0}$ & $\mathbf{1 0 0 , 0}$ & $\mathbf{1 0 0 , 0}$ \\
\hline Total Geral (A+B+C) & & & & & \\
\hline Trabalhadores (agric., pe- & & & & & \\
cuária e ativ. extrativas) & 0,0 & 1,1 & 1,5 & 32,0 & 18,7 \\
Artesãos/ofícios urbanos & 3,2 & 12,6 & 13,8 & 20,2 & 16,2 \\
Comércio e serviços & 10,6 & 35,4 & 32,5 & 10,0 & 17,4 \\
Lavradores & 4,6 & 6,3 & 34,6 & 33,8 & 28,8 \\
Profissionais liberais & 19,1 & 7,4 & 1,6 & 0,6 & 3,4 \\
Proprietários & 51,2 & 27,4 & 9,7 & 1,0 & 10,6 \\
fazendeiros & 32,2 & 5,7 & 3,4 & 0,5 & 5,1 \\
demais (propriedades & 19,1 & 21,7 & 6,3 & 0,5 & 5,5 \\
urbanas e capital dinheiro) & 10,2 & 8,0 & 4,9 & 0,8 & 3,4 \\
Setor público & 1,1 & 1,7 & 1,5 & 1,5 & 1,4 \\
Não identificados & $\mathbf{1 0 0 , 0}$ & $\mathbf{1 0 0 , 0}$ & $\mathbf{1 0 0 , 0}$ & $\mathbf{1 0 0 , 0}$ & $\mathbf{1 0 0 , 0}$ \\
\hline Total & & & &
\end{tabular}

Fonte: Elaboração própria, a partir das listas de qualificação de votantes.

Em conclusão, pode-se afirmar que os trabalhadores ocupados em profissões de menor renda média anual (calculada para o grupo dos qualificados) são uma parcela significativa no universo de votantes. A classificação profissional dos votantes discriminada pelas faixas de 
renda (Tabela 13) permite avaliar, como visto, quem pode votar e quem pode ser eleito para os diversos cargos, segundo suas ocupações. Assim, os profissionais dos grupos de menor renda média são qualificados, mas em sua grande maioria não podem ser eleitos. Como conseqüência, a representação política estava restrita à elite local composta, primordialmente, por proprietários e profissionais liberais, seguidos por aqueles que se dedicavam ao comércio/serviços e pelos que trabalhavam no setor público.

A Tabela 14 apresenta um resumo da distribuição dos qualificados discriminada segundo as faixas de renda definidas pela legislação eleitoral. Mostra que, no total dos qualificados, o peso dos eleitores de menor renda é expressivo, fato que, por definição, não se traduz na possibilidade de acesso a cargos de representação política. Dessa forma, dentre os qualificados da paróquia de Natividade nenhum deles poderia eleger-se deputado ou senador, visto que ninguém possuía a renda exigida pela lei. Para apenas $23,4 \%$ de seus cidadãos qualificados, estava aberta a possibilidade de serem eleitores, juízes de paz ou vereadores. A freguesia de São Gonçalo concentrava, também, a maior parcela dos seus qualificados na condição de votantes não elegíveis $(75,7 \%)$, embora $10,3 \%$ de seus qualificados pudessem candidatar-se a deputado e 7,3\% a senador. Já na paróquia de São Salvador, havia uma maior parcela de qualificados com acesso potencial aos cargos de deputado $(32,2 \%)$ e de senador $(19,3 \%)$.

Tabela 14

Distribuição dos Qualificados por Faixa de Renda (\%)

\begin{tabular}{l|c|c|c|c|c}
\hline \multirow{2}{*}{ Paróquias } & \multicolumn{5}{|c}{ Faixa de Renda (em mil réis) } \\
\cline { 2 - 6 } & $\begin{array}{c}\mathbf{1 . 6 0 0} \text { ou } \\
\text { Mais }\end{array}$ & $\begin{array}{c}\text { Entre } \\
\mathbf{1 . 5 9 9} \text { e } \mathbf{8 0 0}\end{array}$ & $\begin{array}{c}\text { Entre } \\
\mathbf{7 9 9} \text { e 400 }\end{array}$ & $\begin{array}{c}\text { Entre } \\
\mathbf{3 9 9} \text { e 200 }\end{array}$ & Total \\
\hline A - São Salvador & 19,3 & 12,9 & 31,6 & 36,3 & 100,0 \\
B - São Gonçalo & 7,3 & 3,0 & 14,1 & 75,7 & 100,0 \\
C- Natividade & 0,0 & 0,0 & 23,4 & 76,6 & 100,0 \\
\hline Total (A+B+C) & $\mathbf{1 1 , 2}$ & $\mathbf{7 , 0}$ & $\mathbf{2 4 , 6}$ & $\mathbf{5 7 , 1}$ & $\mathbf{1 0 0 , 0}$ \\
\hline
\end{tabular}

Fonte: Elaboração própria, a partir das listas de qualificação de votantes (São Salvador, 1876; São Gonçalo, 1878; Natividade, 1878).

Considerando as três paróquias em conjunto, é possível verificar que $57,1 \%$ dos qualificados possuíam uma renda entre 200 mil réis e 400 mil réis, o que lhes subtraía a possibilidade de ocupar cargos eletivos. Em contrapartida, $43 \%$ reuniam as condições necessárias para se tor- 
narem eleitores, juízes de paz ou vereadores, $18,2 \%$ poderiam se candidatar a deputado e apenas $11,2 \%$ estavam aptos a disputar uma vaga no Senado (Tabela 14).

Sendo assim, pode-se afirmar que a análise das listas eleitorais, aqui realizada, reforça a tese de que durante o Império a participação de homens livres pobres no processo eleitoral era ampla, o que é atestado pela expressiva incidência de cidadãos de baixa renda em todas as faixas etárias dos qualificados e também pela presença de um número não desprezível de analfabetos nas listas de qualificação. Entretanto, os qualificados não devem ser vistos como um bloco único de cidadãos, com direitos políticos idênticos, dada a existência de uma parcela importante que vota sem, contudo, poder ser votada.

\section{CONSIDERAÇÕES FINAIS}

Levando-se em conta os critérios de inclusão eleitoral, que por construção legal deixavam de fora a população escrava, as mulheres livres e os homens livres com renda menor que 200 mil réis e/ou menores de 25 anos, é trivial concluir que a legislação eleitoral do período estudado era discriminatória e excludente. Do mesmo modo, não seria possível caracterizá-la como inclusiva, se inclusão eleitoral significar composição do universo de votantes homóloga à composição da população total (população livre/escrava, mulheres/homens, pobres/ricos, alfabetizados/analfabetos, estrutura ocupacional etc.). A natureza da legislação e os requisitos exigidos para a qualificação são, em si mesmos, indutores de sub-representação de diversos grupos sociais na população votante.

Dadas as ressalvas anteriores, alguns resultados encontrados merecem ser destacados. Em primeiro lugar, nas paróquias focalizadas, a taxa de inclusão eleitoral (votantes sobre população total) é menor que a obtida para estimativas da média brasileira do período, fato que, muito provavelmente, reflete o maior peso da população escrava na região. Ainda assim, é similar ou superior às taxas de inclusão avaliadas para alguns países da Europa Ocidental, onde, vale lembrar, não havia escravos na população. Por seu turno, a comparação intraparóquias indicou que as taxas de inclusão tendiam a ser inversamente relacionadas ao grau de urbanização das mesmas. Em outras palavras, paróquias menos urbanizadas apresentavam taxas de inclusão relativamente maiores. 
Em segundo lugar, o perfil da população com direito a voto em Campos, analisado a partir das listas de qualificação de votantes, confirma o padrão encontrado para outros municípios como Curitiba (Cardoso, 1974), São Paulo (Klein, 1995) e Campinas (Magalhães, 1992). Até 1881, quando o direito político de expressiva parcela da população foi severamente restringido pela Lei Saraiva, os documentos atestam a presença de um amplo contingente de pobres entre os qualificados para votar, podendo-se mesmo afirmar que, até aquela data, a maior parte dos votantes era composta por cidadãos pobres ${ }^{27}$. Embora o índice de analfabetismo entre os votantes do Município de Campos fosse, como visto, menor que o encontrado para São Paulo, a participação dos analfabetos mostrou-se também relevante.

A grande freqüência de eventos eleitorais, as taxas de inclusão similares ou superiores às verificadas para alguns países da Europa Ocidental, o expressivo peso de homens pobres (na sua maior parte trabalhadores ligados à agricultura, à pecuária e ao extrativismo; lavradores; artesãos urbanos) no universo de votantes, assim como a presença de um contingente não desprezível de analfabetos, sugerem uma realidade eleitoral inclusiva, se avaliada pelos critérios de seu tempo. A função que essa circunstância desempenhava para a afirmação de práticas e instrumentos de dominação política, como, por exemplo, o clientelismo, parece ter sido importante, porém constitui tema que está fora do escopo deste trabalho.

Vale, por fim, sublinhar que não decorre das constatações anteriores a conclusão de que o Brasil imperial experimentava uma realidade política inclusiva e democrática. Como sabido, tratava-se de uma sociedade marcada pela escravidão, pela exclusão social e pela pobreza. Instituições modeladas a partir das experiências dos países mais desenvolvidos e indicadores de uma realidade eleitoral que não vedava a presença de pobres e analfabetos entre votantes conviviam, lado a lado, com exclusão econômica e concentração do poder político.

(Recebido para publicação em outubro de 2002)

(Versão aprovada em maio de 2003) 


\section{NOTAS}

1. Atualmente, apenas dois países ultrapassam o Brasil na dimensão do eleitorado: os Estados Unidos e a Índia.

2. Em 1881, com a Lei Saraiva, as eleições passaram a ser diretas.

3. Pela legislação eleitoral do período, as exigências de renda eram as seguintes: 200 mil réis para ser apenas votante (não elegível); 400 mil réis para ser eleitor (votar nas eleições secundárias), juiz de paz e vereador; 800 mil réis para ser deputado e 1.600 mil réis para ser senador.

4. Salvo pouquíssimas exceções, os livros didáticos trabalham superficialmente o tema, induzindo quase sempre à idéia de exclusão nas eleições do Império (ver Nadai e Neves, 1990:140; Vicentino e Dorigo, 1997:171-172; Cotrim, 1999:167-168; Koshiba e Pereira, 1996:125).

5. Na década de 1870 , o percentual de votantes inscritos em relação à população era de 7\% na Inglaterra, 2\% na Itália, 2,5\% na Holanda, 9\% em Portugal e 13\% no Brasil (ver Carvalho, 2001).

6. São documentos produzidos durante o alistamento eleitoral do Império que continham informações importantes sobre os votantes. Passaram a se denominar "censos eleitorais" a partir de 1881.

7. Dados extraídos do relatório do presidente da Província do Rio de Janeiro, Luiz Pe-

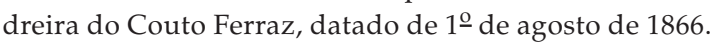

8. A Câmara Municipal compunha-se de sete vereadores se a sede do município fosse uma vila e de nove se a sede fosse uma cidade.

9. O coeficiente eleitoral era obtido mediante a divisão do número de eleitores pela quantidade de vagas disputadas para a Câmara Municipal e Assembléia Provincial.

10. Processo de alistamento eleitoral da época. Até 1875 , a qualificação de votantes era anual e realizada na $3^{\underline{a}}$ dominga do mês de janeiro. A partir desta data (Lei do Terço), fazia-se de dois em dois anos. Com a Lei Saraiva (1881), as grandes transformações implantadas exigiram uma extensa revisão eleitoral, além de alistamentos anuais que eram realizados em setembro.

11. Monitor Campista (15/7/1877:1). Essa percepção está contida no Livro sobre o Brasil, escrito pelo correspondente do jornal em Liverpool, cujos trechos eram publicados em seqüência no Monitor Campista com o título de "O Brazil".

12. Até essa data, as listas eram bastante simplificadas e continham apenas o nome, a ocupação e o estado civil.

13. Os resultados encontrados estão em certa medida superestimados, visto que foram calculados a partir de dados populacionais do Censo de 1872 e da contagem de votantes com base em listas de qualificação de anos posteriores: 1876 para São Salvador e 1878 para São Gonçalo e Natividade.

14. Segundo o Censo de 1872, a população escrava representava cerca de $15 \%$ da população brasileira. Para a média das três paróquias estudadas essa proporção era de $39 \%$. 


\section{Neila Ferraz Moreira Nunes}

15. Os votantes com menos de 25 anos constituem $0,04 \%$ dos votantes de São Salvador, 1,7\% dos de São Gonçalo e 1,5\% dos de Natividade. Na média, considerando as três paróquias no conjunto, representavam apenas $1 \%$ dos votantes.

16. O mesmo acontece com a população votante de Campinas no mesmo período (Magalhães, 1992:129-130).

17. O limite de $600 \mathrm{mil}$ réis de renda anual foi considerado o divisor entre os votantes mais pobres e mais ricos. Qualquer corte que separe mais ricos e mais pobres sempre constitui um ato arbitrário, passível de questionamento. Na verdade, o limite aqui adotado levou em consideração a observação de José Maria da Silva Paranhos, futuro Visconde do Rio Branco, que em 1867, por ocasião da discussão do projeto de reforma tributária, afirmou: "o imposto sobre os vencimentos dos empregados públicos [...] não excetua vencimentos que mal chegam para a subsistência de um homem". Como o imposto atingia uma faixa de renda que variava de 600 a $1.200 \mathrm{mil}$ réis de renda anual, sua fala indica que 600 mil réis estava no limite da subsistência (ver Buesco, 1981:186).

18. Uma discussão mais rigorosa sobre a questão da representação dos mais pobres nas diversas faixas etárias da população votante exigiria avaliar se estes estavam sub-representados ou sobre-representados em cada faixa de idade. Em outras palavras, demandaria comparar a participação dos mais pobres em cada faixa etária dos votantes com a participação dos mais pobres na mesma faixa etária da população total. A inexistência de dados discriminando a população total da região estudada por faixa etária impediu tal cálculo.

19. O índice de Gini é a medida mais conhecida para se avaliar o grau de desigualdade na distribuição de renda de um país ou região. Ele varia de zero a um (quanto mais próximo da unidade, mais desigual é a distribuição de renda). Uma situação de distribuição ótima (em relação à qual não haveria alternativa melhor) seria aquela em que a renda dos indivíduos fosse igual à renda média da região ou do país em foco. Todos os indivíduos teriam a mesma renda e, portanto, poderíamos constatar que os $10 \%$ mais pobres (na verdade não haveria mais pobres) deteriam 10\% da renda total; $20 \%$ reteriam $20 \%$ da renda e assim por diante até que $100 \%$ dos indivíduos controlariam $100 \%$ da renda. Uma situação de desigualdade seria, por exemplo, aquela em que os $10 \%$ mais pobres detivessem apenas $2 \%$ da renda e assim por diante, e os $10 \%$ mais ricos mais que $10 \%$ da renda total, por exemplo, $40 \%$.

20. Este resultado pode estar influenciado pelas listas, já que em Natividade todos os não elegíveis estão registrados com renda de 200 mil réis e todos os elegíveis com renda de 400 mil réis.

21. Mais pobres: os de renda inferior a 600 mil réis; mais ricos: os de renda igual ou superior a 600 mil réis. Na Tabela 6 , os mais pobres correspondem à faixa acumulada de até 500 mil réis, dado que não há declaração de renda correspondente ao intervalo entre 500 e 599 mil réis.

22. A análise da participação dos analfabetos nos qualificados de Natividade está prejudicada pela alta incidência de qualificados para os quais não há registro de escolaridade ( $26 \%$ do total).

23. Segundo Alvarenga (1884), em 1881, havia vinte escravos alfabetizados na paróquia de São Salvador, seis na de São Gonçalo e nenhum na de Natividade. Em con- 
seqüência, a taxa de alfabetização da população escrava das três paróquias consideradas em conjunto era da ordem de $0,2 \%$.

24. Segundo dados do Censo de 1872, a taxa de analfabetismo entre homens livres era de $77,4 \%$ e entre as mulheres livres, de $85,9 \%$.

25. O grande número de lavradores encontrado nas listas justifica o seu tratamento em uma rubrica à parte. Pelas informações das listas, pode-se inferir que eram, em sua grande maioria, pobres. Sua renda média anual (381 mil réis) era inferior somente à renda média encontrada para o grupo de trabalhadores da agricultura, pecuária e atividades extrativas, e apenas $2,6 \%$ do seu total possuíam renda anual igual ou superior a 600 mil réis. Formavam um grupo de trabalhadores que lidavam com a terra, podendo ser meeiros, foreiros ou pequenos proprietários.

26. Ver nota 25.

27. Em 1876/1878, possuíam renda mínima (até 399 mil réis), 57\% dos qualificados em Campos dos Goytacazes, 69\% em Campinas e 66\% em Curitiba. Nesse mesmo período, o percentual daqueles que auferiam renda anual de até 500 mil réis era de: em Campinas, quase $90 \%$ da população qualificada e em Curitiba, $84 \%$, o que indica presença expressiva da população de baixa renda no universo dos votantes.

\section{REFERÊNCIAS BIBLIOGRÁFICAS}

ALENCAR, José de. (1997) [1868], Systema Representativo. Brasília, Senado Federal (edição facsimilar).

ALVARENGA, João. (1884), Almanak Mercantil, Industrial, Administrativo e Agrícola da Cidade e do Município de Campos dos Goytacazes, para 1885. Campos dos Goytacazes, Typographia do Monitor Campista.

BUESCO, Mircea. (1981), “No Centenário da Lei Saraiva”. Revista do Instituto Histórico e Geográfico Brasileiro, nㅇ3으, Rio de Janeiro, pp. 178-186.

CARDOSO, Jayme Antônio. (1974), A População Votante de Curitiba, 1853-1881. Dissertação de Mestrado em História, UFPR, Curitiba.

CARVALHO, José Murilo de. (1988), Teatro de Sombras. Rio de Janeiro, Vértice/IuPERJ. . (2001), Cidadania no Brasil - O Longo Caminho. Rio de Janeiro, Civilização Brasileira.

COTRIM, Gilberto. (1999), História e Consciência do Brasil. São Paulo, Saraiva.

FAORO, Raymundo. (1998), Os Donos do Poder. São Paulo, Globo.

HOLANDA, Sérgio Buarque de (org.). (1972), História Geral da Civilização Brasileira. São Paulo, Difel, Tomo II, vol. 5.

KLEIN, Herbert S. (1995), “A Participação Política no Brasil do Século XIX: Os Votantes de São Paulo em 1880". Dados, vol. 38, n으, pp. 527-544. 
KOSHIBA, Luiz e PEREIRA, Denise Manzi Frauze. (1996), História do Brasil. São Paulo, Atual.

LEAL, Victor Nunes. (1986), Coronelismo, Enxada e Voto. São Paulo, Alfa-Ômega.

LINHARES, Maria Yedda. (1979), "As Listas Eleitorais do Rio de Janeiro no Século XIX". Revista Brasileira de Estudos Sociais, no 48, UFMG, pp.121-153.

MAGALHÃES, Wanda Moreira. (1992), Eleitores e Eleitos: Os Agentes de Poder em Campinas na Segunda Metade do Século XIX. Tese de Doutorado em História, FFCH/USP, São Paulo.

NADAI, Elza e NEVES, Joana. (1990), História do Brasil: Da Colônia à República. São Paulo, Saraiva.

NICOLAU, Jairo. (2002), "A Participação Eleitoral no Brasil", in L. Werneck Vianna (org.), A Democracia e os Três Poderes no Brasil. Belo Horizonte/Rio de Janeiro, UFMG/IUPERJ/FAPERJ.

SOUZA, Francisco Belisário de. (1979) [1872], O Sistema Eleitoral no Império. Brasília, Senado Federal/UnB.

VICENTINO, Cláudio e DORIGO, Gianpaolo. (1997), História do Brasil. São Paulo, Scipione.

\section{ABSTRACT \\ The Electoral Experience in Campos dos Goytacazes (1870-1889): Frequency of Elections and Voter Profile}

This article analyses several dimensions in the Brazilian electoral experience in the 19th century (1870-1889), based on evidence from the municipality of Campos dos Goytacazes, Rio de Janeiro State. The study focuses on three main questions: frequency of elections, voter registration rates, and the profile of qualified voters. According to data from the Rio de Janeiro State Archives and Campos dos Goytacazes Municipal Archives, ordinary citizens voted frequently during the period studied, sometimes more than once a year. Data from the "Voter Qualification Lists" in the municipality were used to calculate the voter registration rates (number of registered voters divided by the population) and establish a profile of voters in the region based on age, occupation, schooling, and income. The voter profile included a large share of both illiterate and low-income voters, which nonetheless did not mean a democratization of the exercise of political power in a slave-owning society marked by heavy social exclusion and poverty.

Key words: elections; frequency of elections; political participation; voter profile 
RÉSUMÉ

L'Expérience Électorale à Campos dos Goytacazes (1870-1889):

Participation aux Élections et Profil de la Population apte à Voter

Dans cet article, on examine quelques dimensions de l'expérience électorale brésilienne au XIXe siècle (1870-1889) à partir de données concernant la municipalité de Campos dos Goytacazes (État de Rio de Janeiro). On y repère trois questions principales: la participation aux élections, les taux d'inclusion électorale et le profil de la population apte à voter. La présence aux urnes, vérifiée à partir de données prélevées dans les Archives Publiques de l'État de Rio de Janeiro et de la municipalité de Campos dos Goytacazes, révèle une réalité où le citoyen ordinaire votait souvent, parfois plus d'une fois par an. Dans les "Listes de Qualification de Votants" de cette municipalité, on a trouvé des informations permettant de calculer des indicateurs d'insertion électorale (votants par rapport à la population) et de tracer le profil des électeurs de la région par le moyen de données concernant l'âge, la profession, la scolarité et le revenu. Le profil de la population votant indique que le nombre de citoyens illéttrés y était important, de même que la participation relative de la population à faible revenu; cela ne signifie pourtant pas une démocratisation de l'exercice du pouvoir public, puisqu'il s'agissait d'une société esclavagiste, marquée par des niveaux certains d'exclusion sociale et de pauvreté.

Mots-clés: élections; participation aux élections; insertion électorale; profil de la population votant 